\title{
What a new economic paper on reward and performance should address?
}

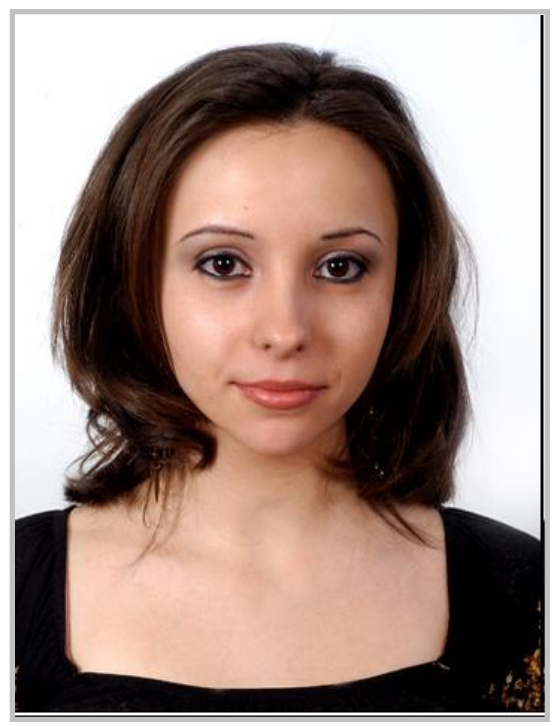

West University of Timisoara, Faculty of Economics and Business Administration E-mail:oana.bogdan@e-uvt.ro

The reward policy provides the necessary framework for a fair share of the newly created value to go to employees; ensures the coordination of the interests of the social partners; expresses a certain collective, egalitarian or individual philosophy, covering, at the same time, other aspects such as: reward levels, performance remuneration, the ratio between internal and external equity, type of salary structure, flexible approach or flexibility of reward systems, etc. [A. Manolescu, Human Resources Management, Autonomous Printing Office (I. Coresi), Bucharest, 1998, p. 123].

In recent years, the Romanian economic literature has known several works on concepts, methods and procedures dedicated to theory and practice in the field of human resources reward. One of them is the one elaborated by Ionel Bostan, Reward and performance in the competitive economy, published at TipoMoldova Publishing House, Iasi, 2010 [1]. It is approached here that wages were not always related to the real efficiency of the activity submitted by economic agents, which led to the idea that there was "a totally non-stimulating system of egalitarian distribution, with negative consequences on increasing labor productivity and economic efficiency (...)" [1]. However, the firm options for establishing a functioning market economy as evidenced by other works by the author [2-10], and the complexity of subsequent economic problems have 
profoundly influenced the conception and attitude about wages and wage policies. In terms of wage economic theory, the results of research obtained until 10-15 years ago did not provide essential clarifications, "dilemmas and controversies persist: some authors consider the salary a payment for employment or for work, others as a price for the purchase of goods - labor, and others - an amount paid to the one who rents his services" [1]. Right from the beginning of the mentioned work, we notice a persisting idea that the labor force is presented on the labor market as a commodity where it is sold and bought for

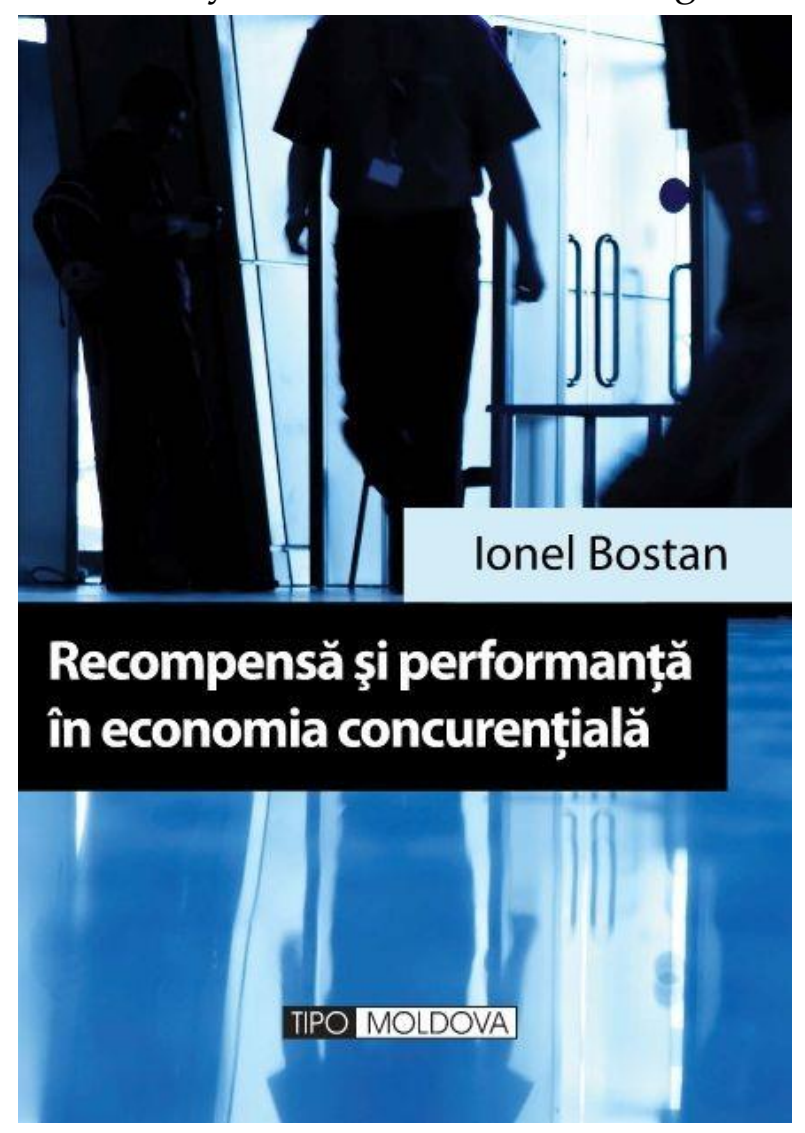

a price that is nothing but the salary, established under the action of supply and demand. Throughout the paper it becomes increasingly clear that "the salary is in a relationship of direct dependence on work and the results obtained being subjected in size to contradictory processes of differentiation and proximityequalization" [1]. Then it is referred to the fact that the salary is influenced to a decreasing extent by the external factors of the company (salary system of the branch, general evolution of prices and tariffs, evolution of social labor productivity, etc.), expanding internal factors at the company level (turnover, costs, profit, productivity, etc.) which led to what can be called "the tendency to detach the salary from the existing situation on the labor market") [1]. In this context, the impact of the regulatory framework is not negligible and the detachment of the salary from the existing situation on the labor market is associated with another trend, more pronounced in certain sectors namely that of the exceeding of the net salary by salary increases and other wage benefits (until the moment of Romania's accession to the EU). The situation was more present in the non-competitive sector (of autonomous administrations and national companies) and was characterized - until 2020 when national rules were established to correct the situation - by the massive increase of the share of personnel rights in the total payroll. Consequently, until that moment the salary functions could not be characterized by normality in the conditions of its "detachment" from its accessories. Last but not least it must be emphasized that many of these accessories were clearly independent of performance, which moreover did not justify distorted 
salary structures. Regarding the salary policy, the mentioned author highlights the fact that it is a complex activity that requires through rigorous calculations the inclusion of all salary characteristics, its functions, its correlations with various economic and social variables as well as taking into account the implications on various interests, often divergent, of the classic partnership triplet: employees (unions), employers and the state. The analyzes undertaken by the author

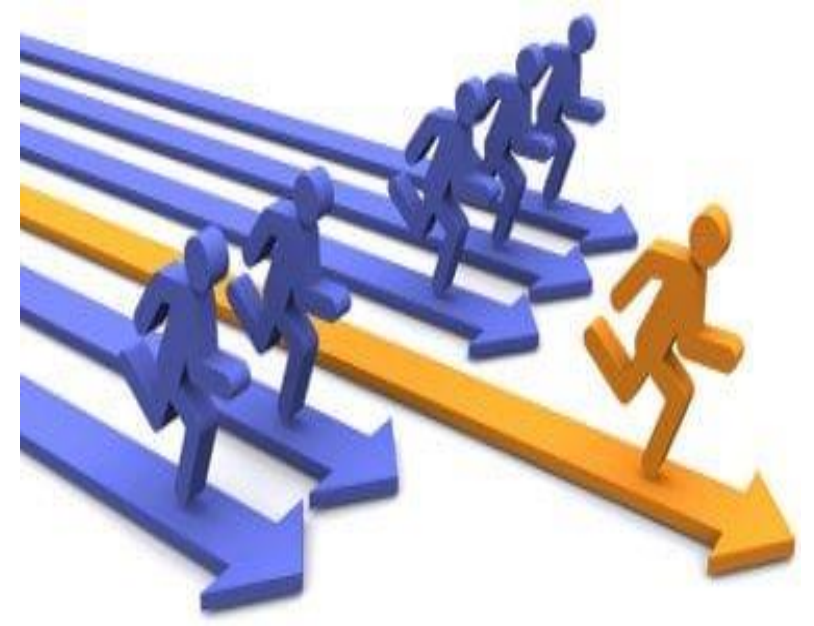

partially found in other of his works [1116] show that for multiple years at the level of companies no policies have been created in terms of labor remuneration, most often being found either the legacy of the bureaucratic style due to the inertia or the misinterpretation of the legislative framework, either transposed to ad litteram copying policies that have been successful in case of other companies. Occasionally the mentioned paper includes landmarks such as: Theoretical foundations regarding the reward of work (Salary: notion, content and functions; Reflection of salary in some theories and economic concepts; Institutional aspects regarding remuneration; Basic principles regarding remuneration). Forms of pay, special rewards and other facilities granted to employees are further discussed. An important share is held by the Regulation of the main elements of the salary system and the taxation of salaries so that afterwards the Salary Policy and economic performance, the involvement of the public authority in the salary policy and the Protection of employees in case of employer insolvency are addressed. The final part contains: Optimal elements in the salary policy at the company level; The motivational effects of various forms of pay and the incentive values of pay in relation to economic efficiency. The moment when the paper appeared (2010), it seems that its content was then at a satisfactory level; today if the updating efforts were resumed, it would be necessary to add other elements in addressing the issue of reward and performance. And this is possible especially because the author has addressed the issues of the competitive environment and in general those of economics and business in a relatively large number of scientific papers [17-59] in his papers or together with other specialists. We take into account the fact that the Law on unitary remuneration of staff paid from public funds has already been showing its results for a good period of time (No. 284 of December 28, 2010). Therefore, some aspects addressed in the paper mentioned at the beginning of our article are no longer valid today (i.e. the exaggerated exceeding of the pure salary 
by salary increases and additions - these being now capped in the case of the public sector). Considering that the staff in the Romanian public sector has a high share in the total number of employees, it was opportune to establish the mentioned law that aimed to "a) harmonize the salary system of the staff in the budget sector with the importance, responsibility, the complexity of the activity and the level of studies necessary for carrying out the activity; b) establishing the basic salaries and the monthly employment allowances as the main element of the salary gain; c) establishing the hierarchy of basic and basic salaries and of the monthly employment allowances, both between the fields of activity and within the same field after an evaluation of the positions, the differences being made according to the following criteria: knowledge and experience; complexity, creativity and diversity of activities; judgment and impact of decisions; influence, coordination and supervision; contacts and communication; work conditions; incompatibilities and special regimes; d) the transparency of the mechanism for establishing the basic salary and of the monthly employment allowances as well as of the other salary rights, etc.". In 2017, it was adopted the Framework Law no. $153 / 2017$ on the remuneration of staff paid from public funds. That created the legislative framework for: “a) the development of a system for substantiating salary policies in the budgetary sector and for monitoring their application; b) the development of a system of distribution of budgetary resources allocated for personnel expenses by establishing the basic salaries in the budgetary sector in order to promote the individual performance; c) the remuneration of the persons holding positions of public dignity". Framework law no. 153/2017 on the remuneration of staff paid from public funds redefines the general performance criteria taken into account when promoting staff paid from public funds or in order to award prizes, these being: "a) professional knowledge and skills; b) the quality, operability and efficiency of the activities carried out; c) improvement of professional training; d) ability to work in a team; e) communication; f) discipline; g) resistance to stress; h) the ability to assume responsibility; i) professional ethics".

The consequences of the putting in practice of the respective normative acts, possible difficulties or strengths, etc., we expect to find all these topics addressed in the editorial project referred to in our article. However, to all this it is vital to add and discuss the "up to date" evolution of the issue of pay at the level of private companies approached from the point of view of the employers, the unions or other state institutions.

One suggestion that we make to the researcher is that he should consider some comparative approaches referring to what is happening in other states whose conditions are close to the economic conditions found in Romania from the point of view of the salary phenomenon. 


\section{Reward and Performance in the Competitive Economy}

\section{Reference}

[1]. Bostan, I. (2010). Recompensa si performanta in economia concurentiala. Editura TipoMoldova, Iasi.

[2]. Bostan, I.; Clipa, F.; Clipa, R.I. (2018). Is Romania a Sustainable Developed Country? An Analysis of Ecological Footprint (EF) in Correlation with Human Development Index (HDI). Logos Universality Mentality Education Novelty: Economics \& Administrative Journal, Volume 3, Issue 1, Pages 5-14.

[3]. Bostan, I.; Popescu, C.; Istrate, C.; Robu, I.B.; Hurjui, I. (2017). The impact of taxation of the domestic economic transactions on the VAT collection through electronic fiscal devices. Amfiteatru Economic 19 (45), 581-594.

[4]. Bostan, I. (2016). International trade of Romania in the context of its low economic potential. CES Working Papers 8 (4), 611-624.

[5]. Bostan, I.; Popescu, C.C.; Dascalu, E.D.; Firtescu, B. (2016). The European Union cohesion policy and external migration in Romania. Multistage analysis. Rev. Cerc. Interv. Soc., Vol. 54, 96-114.

[6]. Bostan, I.; Onofrei, M.; Popescu, C.C.; Lupu, D.; Firtescu, B. (2018). Efficiency and Corruption in Local Counties: Evidence from Romania. Lex Localis - Journal of Local Self-Government. Vol. 16, No. 1, pp. $215-229$.

[7]. Clipa, F.; Bostan, I.; Clipa, R. (2016). Financial audit as a manifestation of institutional entrepreneurship. Knowledge Horizons - Economics, 8 (3), 33-37.

[8]. Bostan, I.; Lazar, C.M.; Asalos, N.; Munteanu, I.; Horga, G.M. (2019). The three-dimensional impact of the absorption effects of European funds on the competitiveness of the SMEs from the Danube Delta. Industrial Crops and Products, 132, 460-467.

[9]. Anton, S.G.; Bostan, I. (2017). The Role of Access to Finance in Explaining Cross-National Variation in Entrepreneurial Activity: A Panel Data Approach. Sustainability, 9 (11), 1947.

[10]. Bostan, I. (2010). Controlul financiar al afacerilor. Bucuresti: Universul Juridic.

[11]. Bostan, I.; Condrea, P.; Burciu, A.; Morariu, A. (2009). HRM Motivational Component: Maslow and Alderfer. Contrast Perspectives. International Conference. SSRN. http://dx.doi.org/10.2139/ssrn.1340959.

[12]. Bostan, I. (2005). Managementul recompensei. Suceava: Editura Universităţii "Ştefan cel Mare".

[13]. Bostan, I. (1999). Recompensarea factorului muncă. Iaşi: Media Tech.

[14] Bostan, I.; Bîrcă, A.; Țurcanu, V.; Sandu, C.B. (2018). Systemic Approach to Management Control through Determining Factors. Journal of Risk and Financial Management, 11(4), 1-20.

[15]. Nicula, V.C., Firtescu, B.N., Bostan, I. (2017). Organizational Performance Management at a Strategic Level. Advanced Systems and Tools. Journal for Ethics in Social Studies, 1(1), 27-38. https://doi.org/10.18662/jess/04

[16]. Bostan, I. (2012). The balanced scorecard (BSC) implications on the increase of public companies performance. African Journal of Business Management, 6 (22), 6465.

[17]. Bostan, I.; Grosu, V.; Iancu, E. (2009). The role and importance of economic and financial information in corporate governance. Annales Universitatis Apulensis: Series Oeconomica, 11 (1), 163.

[18]. Lazăr, C.M.; Hurjui, I.; Asaloş, N.; Bostan, I. (2019). Audit of Forest Restitution Process. Some Findings Regarding the Romanian Space in the Post-Communist Stage. Logos Universality Mentality Education Novelty: Law, 7(2), 66-79. https://doi.org/10.18662/lumenlaw/28

[19]. Socoliuc, O.R.; Bostan, I.; Ignat, A. (2018). Pleading for a Good Cooperation between Institutions and Organisations in the Process of Acquiring Sustainable Development. Case Study on Romanian Agricultural Cooperatives. Acta Universitatis Danubius. Relationes Internationales, 11(1).

[20]. Vodă, A.I.; Bostan, I.; Țigănaş, C.G. (2018). Impact of macroeconomic and healthcare provision factors on patient satisfaction. Current Science (00113891), 115(1). 
[21]. Bostan, I.; Firtescu, B.N.; Toderascu, C. (2018). Exchange Rate Effects on International Commercial Trade Competitiveness. J. Risk Financial Manag., 11(2), 19; doi:10.3390/jrfm11020019, https://www.mdpi.com/1911- 8074/11/2/19/htm

[22]. Voda, A.I.; Bostan, I. (2018). Public Health Care Financing and the Costs of Cancer Care: A CrossNational Analysis. Cancers, 10 (4), 117.

[23]. Popescu, C.C.; Bostan, I. (2016). Gold coinage. Case study: Romania and Republic of Moldova. Ecoforum Journal, 5 (2(9)), 236-240.

[24]. Bostan, I.; Nicula, C. (2017). Interventions on the legal framework of financial-budgetary reasons of national defense. The 19rd International conference "Scientific research and education in the Air Force Henri Coanda", AIR FORCE ACADEMY, pp. 49-56, DOI:10.19062/2247-3173.2017.19.2.7, Braşov, May $25-27$.

[25]. Roman, T.; Lazar, C.; Manolica, A.; Bostan, I. (2016). The current trends and opportunities in the industry of medical tourism. Journal of tourism - Studies and research in tourism, 22, 58-63.

[26]. Bostan, I. (2016). Investigating the effectiveness of programs on health financing based on audit procedures. Iranian Journal of Public Health, Vol. 45, No. 8, Aug, pp. 1074-1079.

[27]. Bostan, I.; Lazar, C.M.; Hurjui, I.; Asalos, N. (2019). Analysis of the Formation and Allocation of Resources Directed at Funding Environmental Projects and Programmes (EPP). Logos Universality Mentality Education Novelty: Political Sciences and European Studies, 5(1), 46-58. doi: 10.18662/lumenpses/08

[28]. Bostan, I.; Roman, T.; Manolică, A.; Morariu, A.; Năstase, C.; Asaloș, N. (2016). Changing attitudes towards the environment by using corporate social responsibility (CSR) campaigns in the oil industry. Environ Eng Manage J, 15(6).

[29]. Bostan, I.; Dascălu, E.D. (2016). Strengthening the Sustainability of Public Finances by means of Financial Law focused on exercise Control and Audit activity. Ecoforum, Vol. 5, Issue 1(8), pp. 387-393.

[30]. Bostan, I.; Grosu, V. (2010). The Role of Internal Audit in Optimization of Corporate Governance at the Groups of Companies. Theor. Appl. Econ., 17, 63-84.

[31]. Bostan, I.; Grosu, V. (2010). Economical and managerial influences in the public health systems. Revista Română de Bioetică, 8(2):97-103.

[32]. Bostan, I.; Burciu, A.; Condrea, P. (2010). Trends of the communitarian cohesion policies and advertising for eco-investments. Environ Eng Manag J, 9(6):847-851.

[33]. Bostan, I.; Onofrei, M.; Dascălu, E.D.; Fîrțescu, B.; Toderașcu, C. (2016). Impact of sustenaible environmental expenditures policy on air pollution reduction, during European integration framework. Amfiteatru Economic, 18 (42), 286-302

[34]. Bostan, I. (2003). Controlul fiscal. Iaşi: Polirom.

[35]. Mates, D.; Grosu, V.; Hlaciuc, E.; Bostan, I.; Bunget, O.; Domil, A.; Moraru, M.; Artene, A. (2015). Biological assets and the agricultural products in the context of the implementation of the IAS 41: A case study of the Romanian agro-food system. Arch. Biol. Sci., 67, 705-714. DOI:http://dx.doi.org/10.20961/jab.v19i2.449.

[36]. Bostan, I. (2005). Guidelines in the audit of Risk assessment. Comunicare susținută cu ocazia Conferinţei, Probleme actuale ale situației ale situatiei social-economice a Republicii Moldova, organizată de Facultatea de Ştiințe Economice a Universităţii de Stat, Vol. 1, Pages 215, Publisher: USM Chisinau.

[37]. Bostan, I.; Burciu, A.; Condrea, P.; Durac, G. (2009). Involvement of legal responsibility for severe acts of pollution and noncompliance. Environ Eng Manage J, Vol. 8, Issue: 3, Pages: 469-473.

[38]. Bostan, I. (2016). Leveraging Sustainability as Budgetary resources through Financial Law Instruments. Annals "Constantin Brâncuşi" University, Economy Series, 33-42.

[39]. Bostan, I. (2016). Pro sustainable development: The influence of the law of entropy on economic systems. Environ Eng Manag J, 15 (11), 2429-2432. 
[40]. Bostan, I. (2016). Considerations on insufficient legal regulation of special allocations made by the central executive authority. Journal of Public Administration, Finance and Law, 9 (1), 119-124.

[41]. Bostan, I. (2014). Juridical tools of Governmental nature used to mitigate various difficulties of the Financial and Budgetary System. Annals of the Alexandru Ioan Cuza University-Economics, 61 (2), 133148.

[42]. Bostan, I.; Firtescu, B.N.; Nicula, V.C. (2018). The Role of Supreme Audit Institutions in Promoting and Strengthening Ethics and Integrity in the Public Sector. Possible Models and Tools to Follow. Journal for Ethics in Social Studies, 2(1), 43-52, https://doi.org/10.18662/jess/08

[43]. Socoliuc, O.R.; Bostan, I.; Ignat, A. (2018). Pleading for a Good Cooperation between Institutions and Organisations in the Process of Acquiring Sustainable Development. Case Study on Romanian Agricultural Cooperatives. Acta Universitatis Danubius. Relationes Internationales, 11(1).

[44]. Bostan, I. (2016). An analysis of the "bio" / "eco" products market, referring to the EU and Romania. CES Working Papers, 1 (8), 33-44.

[45]. Tinică, G.; Bostan, I.; Grosu, V. (2013). Corelaţii privind creşterea economică şi evoluţia costurilor aferente maladiilor cronice. Revista Română de Bioetică, 8 (3), 15-24.

[46]. Pohoaţă, I.; Socoliuc, O.; Bostan, I. (2013). The Economic Impact of Religious Tourism on The North East Region of Romania. European Journal of Science and Theology2, 9 (2), 195-204.

[47]. Bostan, I.; Pohoata, I.; Lazar, C. (2013). State control over commercial transactions with goods from precious metals. Metalurgija, 52 (4), 553-556.

[48]. Burciu, A.; Bostan, I.; Condrea, P.P.; Grosu, V. (2010). Financing the environmental policies in the Communitarian space. Environ Eng Manage J, 9, 1179.

[49]. Bostan, I.; Grosu, V. (2009), Limits on legislative harmonization financial accounting. The 33rd Annual Congress of the American Romanian Academy of Arts and Sciences (ARA), Politechnic International Press Montreal, Quebec, pp. 250- 253.

[50]. Condrea, P.; Bostan, I. (2008). Environmental issues from an economic perspective. Environ Eng Manage J,, Vol. 7, No. 6, pp. 843-850.

[51]. Tinică, G.; Bostan, I.; Grosu, V. (2008). The dynamics of public expenses in healthcare and demographic evolution in Italy and Romania. Revista Romana de Bioetica, 6(3), 56-63.

[52]. Bostan, I.; Mates, D.; Grosu, V.; Socoliuc, M. (2008). Implications of fiscality over accounting in agriculture. Bulletin of University of Agricultural Sciences Cluj-Napoca. Horticulture, Economics and Management Miscellaneous, 65(2):432.

[53]. Burciu, A.; Prelipcean, G.; Bostan, I.; Hapenciuc, V.; Chasovschi, C.; Roman, C.; Popescu, M.; Vancea, R.; Dîmbu, D.; Năstase, C. (2008). Introducere in Management. Burciu, A., Ed.; Editura Economică: Bucharest, Romania.

[54]. Bostan, I. (2010). Considerations on insufficient legal regulation of special allocations made by the central executive authority. Journal of Public Administration, Finance and Law, 9 (1), 119-124.

[55]. Bostan, I. (2016). Impactul sistemului financiar-fiscal asupra derulării schimburilor comerciale internaţionale. Iaşi: Tipo Moldova.

[56]. Bostan, I. (2010). Drept bugetar european. Iaşi: Tipo Moldova.

[57]. Bostan, I. (2008). Drept financiar. Iasi: Editura Tehnopress.

[58]. Bostan, I. (2007). Drept financiar comunitar. Iaşi: Tipo Moldova.

[59]. Bostan, I. (2000). Controlul financiar. Iaşi: Polirom. 